\title{
The Development of University Computing in Sweden 1965-1985
}

\author{
Ingemar Dahlstrand \\ Former affiliation of author: \\ Manager of Lund University Computing Center 1968-1980
}

\begin{abstract}
In 1965-70 the government agency, Statskontoret, set up five university computing centers, as service bureaux financed by grants earmarked for computer use. The centers were well equipped and staffed and caused a surge in computer use. When the yearly flow of grant money stagnated at 25 million Swedish crowns, the centers had to find external income to survive and acquire time-sharing. But the charging system led to the computers not being fully used. The computer scientists lacked equipment for laboratory use. The centers were decentralized and the earmarking abolished. Eventually they got new tasks like running computers owned by the departments, and serving the university administration.
\end{abstract}

Keywords: University, computing, center, earmarked grants.

\section{University Computer Resources before 1965}

In 1964, the Swedish government decided to organize computer resources for the universities. At that time, the universities' access to computing power varied a great deal and was insufficient in most places. Lund was best equipped with SMIL, a welldeveloped BESK copy of its own. Uppsala and Stockholm had access to state-owned BESK and Facit that were heavily loaded, however. Now those three machines were becoming obsolete. In Gothenburg Alwac III E minis were available, and a Datasaab D21, the latter however without supporting service, and the two universities there actually had to rely on Facit time donated by the service bureau Industridata for their computing science education.

\section{The Proposed Organization}

A scheme was set up which included fresh money earmarked for computer time. The universities shared out these grants to departments, which in turn passed them on to teachers and researchers. Universities used the money to pay for computer time from any of the computing centers being set up [1]. It was stressed that the money was intended for computer time. It could be used only to a limited extent for auxiliary services like programming and punching. Soon, Statskontoret interpreted "limited extent" as $8 \%$, a rule that stayed in force as long as the grant existed.

The rules permitted the centers to earn money from external sources (the university administration was an external source) and this made it possible for us to acquire e.g. 
extra equipment without going to Parliament. We will discuss various effects of this below.

The Government's Computer Fund owned the computers and they rented them by the hour. The rental covered amortization over five to six years and interest. Statskontoret (the state's agency for administrative development) managed the fund and had the final word on computer purchases for the whole government sector. Statskontoret was a powerful and competent computer customer, one of the largest in northern Europe, and had forced the vendors to accept a standard contract with strict rules for e.g. delivery tests. They were on the conservative side; that is, the vendor should be able to run a test batch on the equipment offered. They frowned upon selling equipment from blueprints.

\section{The Computer Purchase Phase}

During the first phase from 1965 to 1970 , the centers were in turn equipped with large American computers, starting with Uppsala and ending with Lund, since Lund was reasonably well supplied to start with. The computer fund bought existing computers into the system and hired them out just as the new ones. Some of the purchases Stockholm's in particular - were the subject of intense controversy. Statskontoret wished to create a common center for the universities there and for the FOA, a military research establishment. In those days, we thought that the capacity of a computer grew faster than its price tag, "Grosch's Law"1. There was therefore a temptation to pool resources in order to get something "really big". This marriage - like others of the same kind - proved less than happy, starting with disagreement on the choice of computer (IBM 360/75). There was also a permanent problem of separating the naturally secretive FOA users from the academics and students. Another quarrel broke out when Statskontoret tried to move Gothenburg's IBM 360/50 (which almost at once had to be exchanged for a larger 360/65) to Lund. Waiting at the end of the queue was one thing, but getting the leftovers from Gothenburg was taken as an open insult. Eventually Lund got a Univac 1108.

Users could spend the earmarked money at any of the centers. In fact, many researchers did use centers in other regions during this phase. In particular, Lund people ran a lot of remote batch on Uppsala's CD 3600 and got very good service and some Lund linguists carried on large concordance projects in Gothenburg.

Thus, the centers in some ways functioned as a consortium, though local boards ran them. In 1968, this became more pronounced with the creation of STUD (Styrelsen för Universitetens Datamaskincentraler, i.e. the Board of the University Computer Centers) [2]. STUD controlled budgeting and expenses, created job positions, and checked that the rules were followed. The three medium-size centers - Uppsala, Gothenburg and Lund - were expected to break even, whereas the larger Stockholm center had a surplus that covered the deficit of little Umeå. Though STUD rightfully belonged under the Chancellery of the universities, Statskontoret had permission to appoint its chairperson, giving Statskontoret a double control over our activity.

${ }^{1}$ Langefors has questioned whether Grosch's law ever held. It might have been an illusion, the effect of comparing old and slow computers with new and fast ones. Anyway, it played a role in our deliberations. 


\section{The Build-Up of a Complete Computing Service}

The flow of money for computer time grew as the centers were equipped and by 1970 amounted to some 25 million Swedish kronor yearly (this was when gasoline was about one krona per liter). Including external income, our turnover surpassed 40 million and the centers together employed some 200 people. Financed by this flow we could build up full-scale centers with modern equipment including auxiliary units like paper tape readers and writers and curve plotters. Supporting services included programming, punching and a program library that brought home and put to use libraries like NAG (Numerical Algorithms Group) and IMSL (International Mathematical and Statistical Libraries). I can state flatly that we were quite a bit ahead of the private service bureaux like Industridata (where I came from in 1968 to take over the Lund center).

The centers themselves provided some interesting software like the GUTS timesharing system of Gothenburg and the MIMER database system of Uppsala (named for the fount of wisdom in Nordic mythology). Lund's strong point was an early high quality, ink jet printer, designed by the Department of electrical measurements, and a package of pixel based graphics software. The Umeå center implemented automatic analysis of ECG measurements.

Our sites were on the whole Fortran sites. Algol remained in places and was for instance used a lot in Lund since Univac supplied an Algol compiler made in Norway as a part of Simula. Many other languages were available, but if they could not exchange files and subroutines with Fortran they did not make much of an impact.

\section{The Customers}

The customers were a very varied group. I take my examples mostly from Lund, but the picture was similar over the whole field. There were the number crunchers like the physicists and structure chemists. The medical faculty, including the special population research station of Dalby, made wide use of us for statistics. So did the social scientists. The linguists as mentioned had large concordance projects. Later the Slavics department in Uppsala made a parser for Russian. One could go on and on reciting project titles such as inventory of threatened Nordic landscape types, scintigram analysis of tumor location, allometry in the foot soles of eight sparrow species, disturbed eye movements in psychotic and alcoholic patients, and bilingualism in Yugoslav immigrant children.

The use of computing became broad. Hundreds of people passed through a center every day to submit runs before computing from terminals became a reality.

Many customers used our programming service. We must mention one unexpected benefit. For many customers it was a relief to discuss a project with an interested outsider who was trying to neither steal a good idea nor tear a poor one to pieces. However, the $8 \%$ rule held them back, since programming and punching cost a lot compared to computer time. The humanities had an extra hard time since programs and languages were mainly designed for technicians.

\section{Economic Problems}

About 1970 the computer fund decided to charge annual rates instead of hourly rates. This decision passed almost unnoticed but actually had a profound effect in that the 
centers were now saddled with large fixed costs. At about the same time the government seemingly lost interest in the supply of computer resources for the universities. Grants for computer time were frozen at the level achieved and from then on barely kept pace with inflation. Lund was particularly hit hard since it was the last to receive a computer; it received less money per student than the other regions and it did not achieve parity until 1977.

At the same time, it became imperative to upgrade our installations, first in order to achieve full-scale multiprogramming - we had only spooling of input/output to start with - and secondly to be able to offer computing from dialog terminals.

This meant we had to find external income. What was an extra bonus became a necessity, and it distracted us considerably from our main purpose-to introduce computing to researchers and students. In Lund, they were lucky to get many runs from the county's computing center, which was preparing programs for a coming Univac 1108 and later on from administrative runs and from external projects connected with the ink jet plotter. Eventually 25 to 50 percent of our income came from external sources, with great variations between the centers. Even so, we had to extend amortization time to make ends meet. In the case of Lund, it took us almost nine years to pay off the first computer and all its upgrading, by which time the main CPU was a bit outmoded.

The memory extensions needed for time-sharing were expensive, presumably because our computers were so fast. At one time, I suggested exchanging the Univac 1108 with one module of $64 \mathrm{~K}$ words for a somewhat slower Univac 1106 with three modules, which would have suited us better, at the same cost. The reaction was very negative. Speed still carried prestige, dating from the origin of computing, irrespective of whether we could sell it or not.

In this atmosphere, the right of researchers to run their projects in other regions was in practice suspended. Strong pressure for instance forced the Lund linguists to bring home their concordance projects from Gothenburg.

\section{User Criticism of the System}

The system worked as intended but users found it problematic in several ways. The money allotted was intended for one-shift operation of the centers. The idea was that the departments should find more money from other sources if the earmarked money was not enough. However, these other sources refused to grant computer money, referring to the existence of earmarked money. In Lund, which already operated SMIL more than one shift when the system started, grant money was used up before the term's end in the spring of 1966 so the students could not complete their test runs. Statskontoret had to admit free runs this once. It just would not have worked to stop the Lund people from using a machine they had built themselves. However, this did not solve the principal problem. The customers wanted the hourly rates reduced so the machines could have greater utility. This controversy raged for years until it was solved by introducing nightly low priority runs with low rates.

We had some other public relations problems with our academic customers. One was inherent in our charging money to build up our equipment. They felt that we, the computer people, should fight for more grant money, not push our begging onto our customers. 
Another one was the way their applications for grants were processed. Researchers were used to having their applications judged and cut down, but usually that was done by peer review. In this case, the processing was seen as purely bureaucratic.

Researchers naturally found it hard to predict their need for computer time ahead of actual trial runs. This particular problem we solved in Lund by cancelling overdrafts against unused grants at year's end. Remaining overdrafts (usually 20\%) had to be paid with fresh money. Only once did we actually stop a customer because of an overdraft. It was an extreme case of a researcher running a large graphics program interactively in prime time, in effect stopping everybody else.

A third cause of discontent was the new situation of the computer scientists. They had grown up with SMIL and were used to coming and going in the computer room, having the machine for themselves, seeing the lamps blink and actually hearing the flow of computation. Now they could only watch the computer from behind window glass, reinforced with metal wires. Looking back, it is curious that one did not realize from the start that computer scientists needed computers of their own, as laboratory equipment allowing them to experiment with languages and operating systems.

\section{Decentralization}

By 1977, the centers had fulfilled their first task of supplying powerful computing resources and making them widely used. At the same time, the first round of computers would soon be fully paid. A committee of academicians was formed to consider the future. Now the many controversies between the academics and Statskontoret took their toll. The committee decided that STUD should be disbanded, the centers decentralized, and the flow of grant money un-earmarked [3]. This was by no means an obvious outcome, e.g. the Danish universities' centers were consolidated at about the same time. Thus each of the five regions had a computing center dropped on them and started doing different things with them. We shall now follow the road that Lund travelled.

The immediate effects were not dramatic. The earmarking was relaxed in small steps and the faculties gained some control of the money. Now, the very basis for computing was changing. An investigation by lecturer Gustaf Olsson in 1980 pointed out some important facts [4]:

o The departments were buying mini-computers. From 1980 on the computing center would be supplying less than half of the computing power within the university, and that part would keep shrinking.

o These new computers were more cost-effective than those of the classical producers. They were also easier to run. Olsson therefore proposed a thorough investigation before buying another super computer.

○ The computing center would be needed for other purposes. One was building a local network that would make it possible to reach any computer in the university from a terminal or another computer.

o Another task might be to run computers for the departments that owned them.

- A growing share of computing would be done with ready-made programs.

o Computing would be used by almost everybody in the university. 
A paper from the mathematics and natural science (math-nat) faculty supported this analysis and went farther in some respects. In particular the faculty strongly opposed converting the center's new Univac 1100/80 from hire to purchase, lest our hands again be tied for several years.

Unfortunately, the center did not listen. It bought the 1100/80 with the support of the university administration but in stark opposition to the heaviest component of our regular customer base. This was just one example of how our dependence on external money had undermined the original purpose of supporting students and researchers. Another was the controversy over STUDOK, the system for documenting students' progress and grades. This, students felt, was inflicting on their integrity (and, we may suspect, made it too easy for parents to check on them). The administration had us take the job anyway and we were in no position to refuse, considering the amount of money paid. A third example was the re-wording of the center manager's profile and duties. The chief administrator deleted the sentence saying that the center manager might be performing research as part of the job. The administration wanted a businessperson to manage the center.

\section{The Diverse Interests of the Faculties}

In this situation, the faculties had somewhat different profiles. The math-nat people were already perfectly capable of buying and handling their own computers. The medical faculty could afford to buy all the service they needed from the center. The social sciences were well organized and already had a countrywide cooperation to acquire international databases and interesting program libraries. However, the humanities had not caught up with the rest. They were starved for money and had been held back by the lack of suitable languages and programs. In the scuffle over the grant money they lost out; the committee that divided the grant for good computed the shares according to computer time used over the years, not including programming and punching which would have been fair to the humanists. Thus, decentralization actually resulted in a bad setback to computing in the humanities.

I rather regret we did not use the temporary good economy when the Univac 1108 was paid for to make a strong drive within the university to find those many researchers who had not yet used us and give them a chance to try on the cheap. We should have abolished the $8 \%$ rule immediately when we were decentralized, to get a better picture of true customer needs.

The situation was further complicated by differences within the faculties about how to spend the money once they had received control over it. In each faculty there were people who wanted to use the money to buy their own computers, those who wanted to continue using the center, and finally those who were not interested in computing and wanted to spend the money on other things.

It is interesting to note that when the earmarking was dropped completely in 1980 , the initial effect, lasting about a year, was a marked drop in usage of the center, followed by a bounce back and then a steady rise to ever-greater turnovers. No amount of bickering could stop computer use for long, if there was money available. 


\section{Marking Time}

Things now rolled on for a few years with the center actually taking on all of the tasks proposed by Gustaf Olsson: building the network, running other peoples' computers, and even setting up an agency for distributing personal computers.

The basis for computing changed rapidly in these years. Punched cards were phased out as registration was done from terminals. Tape stations became less used as disk memories kept growing. Special printers and plotters were superseded by pixelbased laser printers. Thus, the need for a central computer to carry lots of extra equipment shrunk drastically. CPUs could be built cheaply and robustly, leading to a flow of minis and personal computers.

\section{Reorganization}

In late 1983, the university started a second investigation. This was a much bigger and more official affair than Gustaf Olsson's. It was headed by the dean of the natural science and technology college and included representatives from all faculties, the students, and the trade unions. Its purpose was to create an organization to assist the computerization of the whole university, including teaching and secretarial work. For the computing center, it turned out to be a rather nasty affair.

The driving force, lecturer Lars Philipson, wished to start a new computation unit, with fresh people, to take over user support and program library. The computing center, in his opinion, had shown it was not equal to the task ahead. Its service bureau function was to be liquidated as fast as possible and the external customers told goodbye, leaving the center with the network building and the running of department computers. The university administration ought to have computers of its own [5].

After intense debate through 1984, the final decision was taken in the university's board. The university administration refused to take over its own computing and in addition have one old and one new computing organization to deal with. The question of one or two organizations had to be put to a vote. The committee's two-organization proposal failed by one vote, the faculty representatives being voted down by a coalition of the administration, the trade unions, and the non-academic board members. The rector of the university very farsightedly came up with 4 million kronor to buy the existing computer off the computer fund, so the center could concentrate on its conversion to new tasks instead of earning external money.

Thus, the computing center changed into a computer center and went on with old and new tasks. The service bureau function withered away gradually and the 1100/80 was not replaced when it went out of production. Nevertheless, the center is still there today, running the network and many hundreds of computers and engaging in all kinds of projects for Lund University.

\section{References}

[1] Statskontoret, brev till K. Maj:t 14.10.1964, Dnr 1964:832, med bilaga Expertrådets utredning, Datamaskiner för utbildning och forskning vid universitet och högskolor (1964)

[2] Riksarkivet SE/RA/420483/420483.02/FV (UKÄs arkiv), Styrelsen för universitetens datacentraler, protokoll 
[3] UKÄ-rapport 13 a, Datorservicegruppen, Datakraft för högre utbildning och forskning (1974)

[4] Lunds universitet, datorresursutredningen, Gustaf Olsson, Slutrapport (1980-04-10)

[5] Arbetsgruppen för utredning av inriktning och organisation av datorverksamheten vid Lunds universitet, Slutrapport (October 1984)

[6] Riksrevisionsverket, Datorcentralerna för högre utbildning och forskning - roll och styrning, Dnr 1985:100

A fuller account of the centers, with focus on the one in Lund, is given in my memoirs, which are deposited at the Technical museum (Tekniska museet) in Stockholm. There you will also find copies of the papers above, except for [2] which is only available at the Riksarvet. Here follows a translation of the references, along with their reference numbers within my deposited papers.

[1'] [XpR] Letter October 14, 1964 from Statskontoret to the government, and attached to it the expert group's proposal that founded the university computing centers, Computers for education and research at universities and colleges (1964)

[2'] Proceedings of the Board of the university computer centers (1968-1977)

[3'] [DSG] Report from the computer service group of the chancellery of universities: Computing power for higher education and research (1974)

[4'] [LTU 0:2] University of Lund, computer resources investigation, Gustaf Olsson: Final report, April 10 (1980)

[5'] [LTU 1:17] University of Lund, working group on direction and organization of computer activity, Final report (October 1984)

[6'] [LTU 2:26] Office of review and auditing, The computer centers for higher education and research (This paper is not cited above, but constitutes a comprehensive survey of the computing centers just before the local reorganizations started to have effect) (1985) 